\title{
Respiratory Diseases of Calves on Dairy Cow Farm
}

\author{
Jovan BOJKOVSKI ${ }^{1}$, Dubravka MILANOV ${ }^{2}$, Sara SAVIĆ ${ }^{2}$, Ana VASIĆ ${ }^{1}$, Nemanja ZDRAVKOVIĆ ${ }^{1}$, \\ Dragan ROGOŽARSKI ${ }^{3}$, Nataša PROKIĆ ${ }^{1}$, Sanja KORICA ${ }^{4}$ \\ ${ }^{1}$ Faculty of Veterinary Medicine, University of Belgrade, Belgrade, Serbia \\ ${ }^{2}$ Scientific Veterinary Institute »Novi Sad", Novi Sad, Serbia \\ ${ }^{3}$ Specilistic Veterinary Institute, Pozarevac, Dunavska 89, 12 Pozarevac, Serbia \\ ${ }^{4}$ Union University "Nikola Tesla", Faculty for Ecology and Environmental Protection, Kosancicev venac \\ 2, 11000 Belgrade, Serbia. \\ *corresponding author: bojkovskki@vet.bg.ac.rs
}

Bulletin UASVM Veterinary Medicine 71(2) / 2014,

Print ISSN 1843-5270; Electronic ISSN 1843-5378

DOI:10.15835/buasvmcn-vm: 10325

\begin{abstract}
Intensive cattle breeding involves a whole series of technological processes, which should allow continued production and optimal use of production capacities. In those conditions new born calves must adapt to different environmental factors, including diet and housing conditions. Diseases of digestive and respiratory organs are the most common health problems in calves during the first months of their life. In this paper, we provide an overview of respiratory diseases of calves on a dairy farm. We monitored health status of calves on a dairy cow farm. Calves show clinical picture of respiratory diseases. In microbiological laboratory wide range of bacteria was isolated from calve lungs and nasal swabs. During one calendar year, the following bacteria were isolated from calve lungs: Pasteurella multocida, Mannheimia haemolytica, Pasteurella spp. Histophilus somni, Haemophilus spp, Trueperella (Arcanobacterium) pyogenes, Escherichia coli, Klebsiella pneumoniae, Pseudomonas aeruginosa, Salmonella Enteritidis, Salmonella Typhimurium. The total of 61 calves was diagnosed with respiratory diseases (34 male and 27 female calves). Number of dead male calves is 24 ( 16 male calves and 8 female calves). Calves with respiratory diseases were approximately 71.62 days old. Dead calves with pathomorphological changes on their lungs were approximately 77.25 days old. Diseases of calves on farms usually have multifactorial etiology, and the most important health disorders in calves on our farms were respiratory diseases. The occurrence of respiratory diseases is highly significant unfavorable result of microclimate conditions, hygienic accommodation and inadequate technological processes
\end{abstract}

Key words: calves, dairy farm, respiratory disease

\section{INTRODUCTION}

Respiratory system diseases in cattle belong to the groups of the economically important for cattle production. In addition to digestive tract diseases, they represent the leading causes of morbidity and mortality on high production dairy farms. On the high production dairy farms in the Republic of Serbia using tie-stall housing system, infectious diseases of the respiratory tract of the calves account for different percentage of the total mortality (Dobrić et al. 1999, Bugarski et al., 2005; Bojkovski et al., 2004, Bojkovski et al., 2008). The mortality rate in the Republic of Serbia ranges between 14.3 and 50\% (Šamanc et al., 1990). Veterinary service has an important role in health monitoring, timely identification of the disease, establishment of etiology of infection and application of the appropriate treatment. A disease known as enzootic pneumonia of calves and cattle is particularly important on high production dairy cow farms in the Republic of Serbia, its etiology in multifactorial and its onset is influenced by a combination of different stress factors and infectious agents (viruses, mycoplasmas and bacteria). The significance of non-infectious factors was evidenced in the experimental conditions, where respiratory syndrome was easy to induce by BHV and Mannheimia haemolytica, but not with other causative organisms (Rogan, 2010).

The ongoing paper presents results of a one-year monitoring of onset of the respiratory diseases of calves and cattle on cow farms, analysis of factors influencing their onset as well as type of the bacteria most commonly isolated from the 
samples of nasal swabs of the diseases animals and parenchymatous organ tissues of the dead animals.

\section{MATERIAL AND METHODS}

The studies were performed on a high production dairy tie-stall housing farm. The farm had 1,000 milking cows, with average milk production of 8,000 L. Serological tests performed in adult animals as well as in calves and cattle of different ages, evidenced antibodies to viruses essential for development of enzootic pneumonia: bovine herpesvirus-1 (BHV1), parainfluenza virus type 3 (Pi3), bovine respiratory sintitial virus (BRSV) and bovine viral diarrhea virus (BVDV). In February, June, July and August, the calves did not show any signs of any respiratory diseases. There was no mixing of different herds on the experimental farm. Great attention is paid to feeding of calves with colostrum as well as to quality of colostrum itself.

Symptoms of respiratory infections were evidenced in 61 calves (34 male and 27 female, while 24 calves died (16 male and 8 female). Average age of the disease and dead calves was 71.62 days and 77.25 days, respectively. For isolation of bacteria, nasal swabs were obtained from the sick calves and lung tissue samples from the dead calves.

Microbiological tests: Nasal swabs and parenchymatous tissue smears were microbiologically processed immediately after arrival to the laboratory. Isolation of bacteria was performed using the following: Columbia blood agar base (Oxoid, Basingstoke, UK, CM0331) with 5\% defibrinated ovine blood and MacConkey agar (Oxoid, CM0007). For isolation of species from Haemophilus (except H. somni) and Actinobacillus genera, factors $\mathrm{V}$ and $\mathrm{X}$ were used (Oxoid, diagnostic disc). The plates were simultaneously incubated under aerobic and microaerophilic conditions (5-10 per cent $\mathrm{CO}_{2}$ ) at $37^{\circ} \mathrm{C}$ for $2-3$ days, and they were examined for bacterial growth every day.

Isolate identification was performed based on the colonial appearance, microscopic appearance (Gram-stained preparations), catalase and oxidase tests and biochemical properties as stated in Quin et al. (1998). Biochemical and serological verification of Salmonella isolates was performed according to SRPS EN ISO 6579:2008.

\section{RESULTS AND DISCUSSION}

Inappropriate passive immunity, exposure to adult animals, poor ventilation, overcrowded housing facilities, wide temperature variations, transportation and other stress factors may lead to development of respiratory infections. Group calf housing contributes to spreading of infections with inhalation being the major transmission pathway of respiratory infections. Clinical signs of pneumonia include nasal discharge, elevated body temperature, decreased appetite and breathing disorders. Administration of antibiotics is necessary however, the results are frequently disappointing. Complete recovery is rare in calves with chronic respiratory infections. Due to the significance of the respiratory system diseases for growth and future productivity of dairy cows, early identification of causes and treatment are of the utmost importance, with elimination of the risk factors being the imperative (Broom, 1991, Bugarski et al., 2005, Radojičić et al., 2014). The most frequent bacterial infections of the respiratory system in calves on the farms in the Republic of Serbia are caused by the following bacteria: Pasteurella multocida Mannheimia haemolytica, Trueperella (Arcanobacterium) pyogenes. In very young calves, Streptococcus Pseudomonas aeruginosa and Haemophilus somni are of the highest importance (Radojičić et al., 2014). The following bacteria were isolated on the high production dairy farm included in the experiment: Pasteurella multocida, Mannheimia haemolytica, Pasteurella spp., Histophilus somni, Haemophilus spp., Trueperella (Arcanobacterium) pyogenes, Nocardioform microorganisms, Pseudomonas aeruginosa, Salmonella Enteritidis, Salmonella Typhimurium (Table 1 and Graph 1). Table 2 presents ratio of sick and dead calves during a calendar year, revealing that major health problem is encountered during the cold days. Graph 2 represents changes in the number of calves within a calendar year. We have studied the ratio of number of dead male and female calves within a calendar year (Table 3). Graph 3 represents changes in number of sick calves within a calendar year. Age of the sick and dead calves expressed in days within a calendar year is presented in Table 4. Graph 4 gives changes in number of dead calves within a calendar year.

Synergistic bacterial and viral actions are also important for onset of respiratory diseases in 
Tab. 1. Results of bacteriological examination of nasal swab samples obtained from the sick calves and parenchymatous tissues of the dead calves

\begin{tabular}{l|c}
\hline Type of isolate & $\begin{array}{c}\text { Number of } \\
\text { isolates }\end{array}$ \\
\hline Pasteurella multocida & 17 \\
Mannheimia haemolytica & 7 \\
Pasteurella spp. & 8 \\
Histophilus somni & 5 \\
Haemophilus spp. & 5 \\
Trueperella (Arcanobacterium) pyogenes & 13 \\
Escherichia coli & 12 \\
Klebsiella pneumoniae & 2 \\
Nocardioform microorganisms & 3 \\
\hline Pseudomonas aeruginosa & 1 \\
Salmonella Enteritidis & 1 \\
\hline Salmonella Typhimurium & 78 \\
\hline Total number of isolates & \\
\hline
\end{tabular}
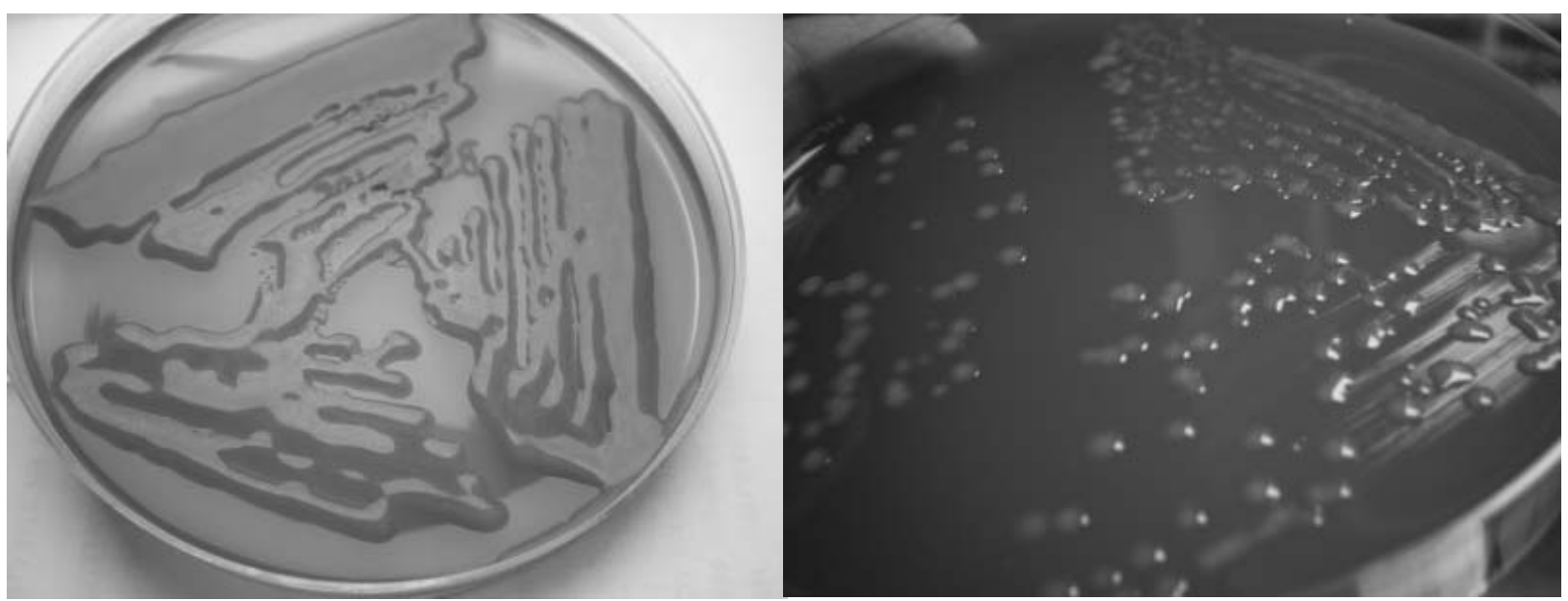

Fig. 1. Klebsiella pneumoniae mucoid colonies on MacConkey agar (left) and Pasteurella multocida on blood agar (right), isolates from the lung tissue of dead calves 


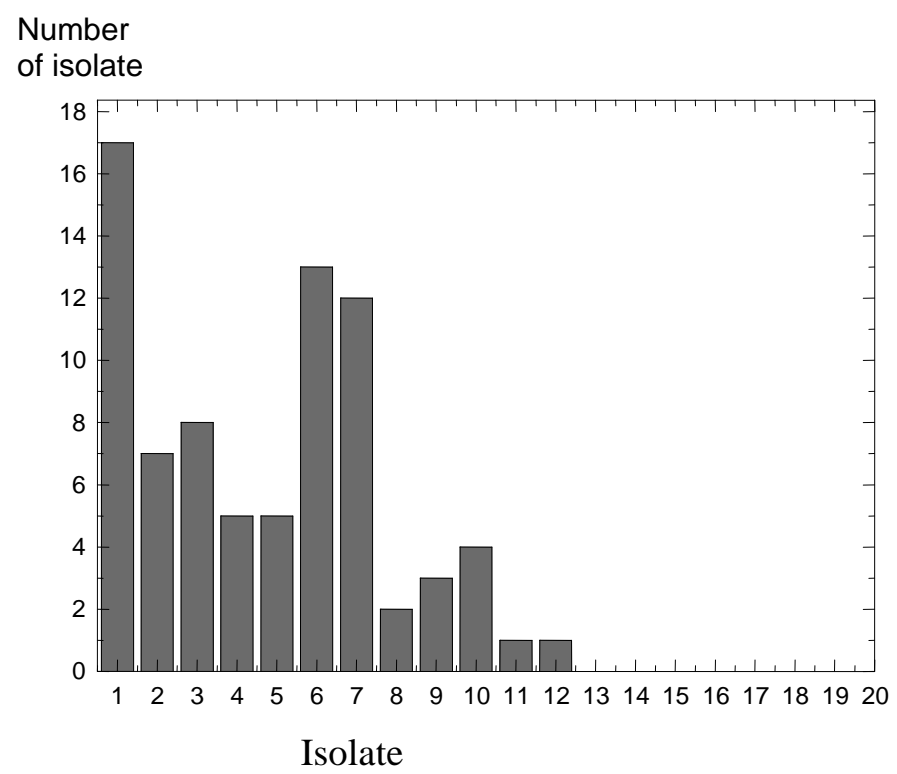

Type of isolate

1 - Pasteurella multocida

2 - Mannheimia haemolytica

3 - Pasteurella spp.

4 - Histophilus somni

5 - Haemophilus spp.

6 - Trueperella (Arcanobacterium) pyogenes

7 - Escherichia coli

8 - Klebsiella pneumoniae

9 - Nokardioformni microbodies

10 - Pseudomonas aeruginosa

11 - Salmonella Enteritidis

12 - Salmonella Typhimurium

Fig. 2. Results of bacteriological examination of nasal swabs obtained from sick calves and parenchymatous tissues obtained from dead calves originating from high production dairy tie-stall housing farm $\mathrm{A}$

Tab. 2. Ratio of sick and dead calves originating from high production dairy tie-stall housing farm A according to months within a calendar year

\begin{tabular}{lcccccc}
\hline Month & $\begin{array}{c}\text { Number } \\
\text { of calves }\end{array}$ & $\begin{array}{c}\text { Number } \\
\text { of sick } \\
\text { calves }\end{array}$ & $\begin{array}{c}\text { \% of sick calves } \\
\text { with respect } \\
\text { to number } \\
\text { of calves }\end{array}$ & $\begin{array}{c}\text { Number of } \\
\text { dead calves }\end{array}$ & $\begin{array}{c}\text { \% of dead calves } \\
\text { with respect } \\
\text { to number of } \\
\text { sick calves }\end{array}$ & $\begin{array}{c}\text { \% of dead calves } \\
\text { with respect to } \\
\text { number of calves }\end{array}$ \\
\hline January & 413 & 7 & 1.69 & 1 & 14.28 & 0.24 \\
\hline February & 0 & 0 & 0 & 0 & 0 & 0 \\
\hline March & 412 & 6 & 1.45 & 2 & 33.33 & 0.48 \\
\hline April & 396 & 2 & 0.50 & 1 & 50.0 & 0.25 \\
\hline May & 399 & 5 & 1.25 & 2 & 40.0 & 0.50 \\
\hline June & 0 & 0 & 0 & 0 & 0 & 0 \\
\hline July & 0 & 0 & 0 & 0 & 0 & 0 \\
\hline August & 0 & 0 & 0 & 6 & 85.71 & 1.29 \\
\hline September & 462 & 7 & 1.51 & 6 & 42.85 & 0.42 \\
\hline October & 421 & 14 & 3.32 & 2 & 22.22 & 1.02 \\
\hline November & 400 & 9 & 2.25 & 4 & 36.36 & \\
\hline December & 389 & 11 & 2.82 & 16 & & 0 \\
\hline Total & 2896 & 61 & & & & 0 \\
\hline
\end{tabular}




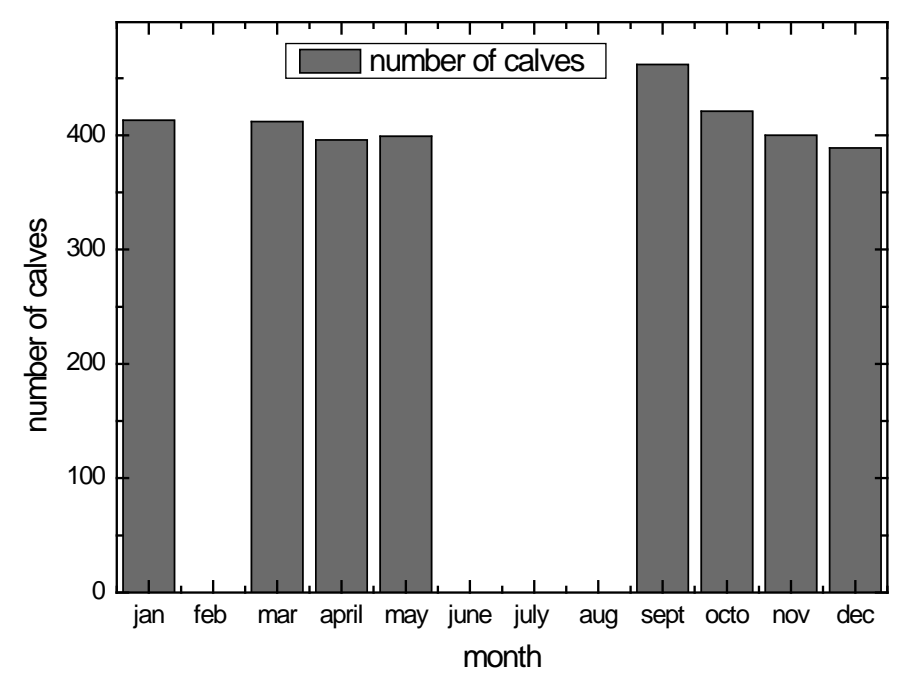

Fig. 3. Changes in number of calves in the experiment within a calendar year.

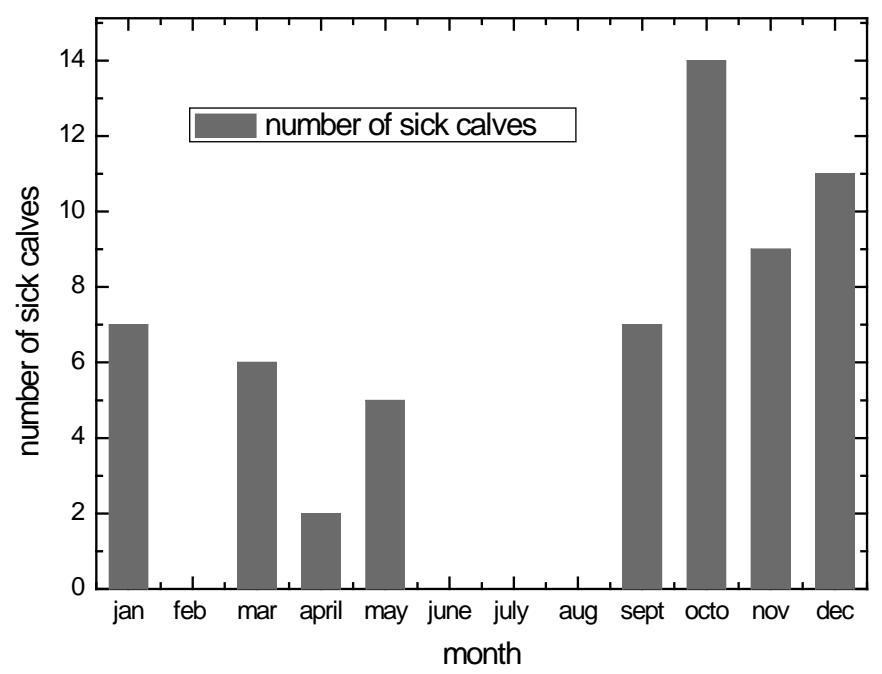

Fig. 4. Changes in number of sick calves within a calendar year

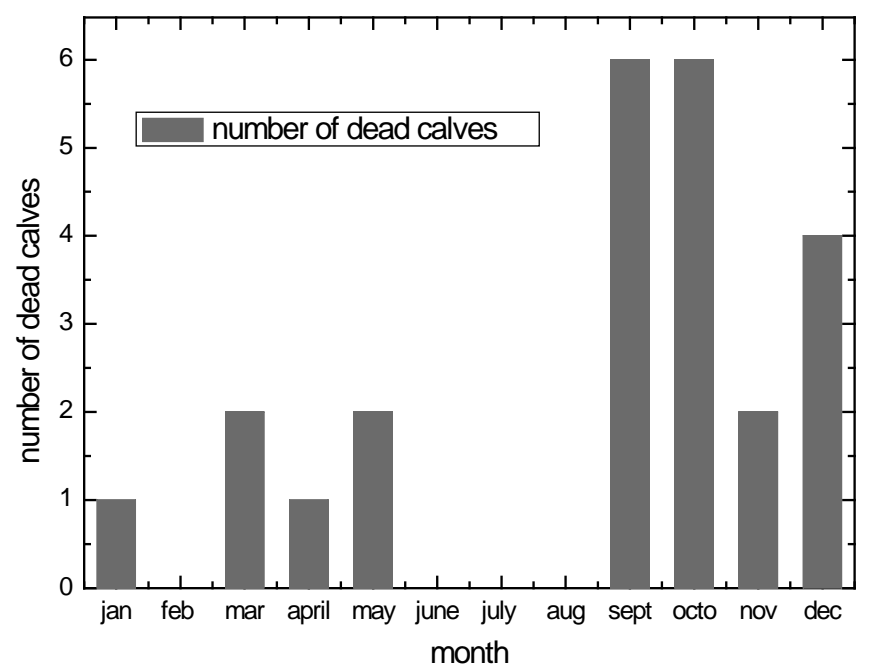

Fig. 5. Changes in number of dead calves within a calendar year 
Tab. 3. Sex ratio of sick and dead calves originating from high production dairy tie-stall housing farm A

\begin{tabular}{|c|c|c|c|c|c|c|c|c|c|c|}
\hline Month & I & II & III & IV & V & VI & VII & VIII & IX & $\mathrm{X}$ \\
\hline January & 7 & 5 & 71.42 & 2 & 28.57 & 1 & - & - & 1 & 100.0 \\
\hline February & - & - & - & - & - & - & - & - & - & - \\
\hline March & 6 & 4 & 66.66 & 2 & 33.33 & 2 & 2 & 100 & - & - \\
\hline April & 2 & 1 & 50.00 & 1 & 50.00 & 1 & 1 & 100 & & \\
\hline May & 5 & 3 & 60.0 & 2 & 40.00 & 2 & 2 & 100 & - & - \\
\hline June & - & - & - & - & - & - & - & - & - & - \\
\hline July & - & - & - & - & - & - & - & - & - & - \\
\hline August & - & - & - & - & - & - & - & - & - & - \\
\hline September & 7 & 3 & 42.85 & 4 & 57.15 & 6 & 3 & 50.0 & 3 & 50.0 \\
\hline October & 14 & 7 & 50.0 & 7 & 50.0 & 6 & 5 & 83.3 & 1 & 16.66 \\
\hline November & 9 & 14 & 44.44 & 5 & 55.55 & 2 & - & - & 2 & 100.0 \\
\hline December & 11 & 7 & 63.63 & 4 & 36.36 & 4 & 3 & 75.0 & 1 & 25.0 \\
\hline Total & 61 & 44 & & 27 & & 24 & 16 & & 8 & \\
\hline
\end{tabular}

I total number of sick calves II number of sick male calves;III \% of sick male calves with respect to total number of the sick calves; IV total number of sick female calves; V \% of sick female calves with respect to total number of sick calves; VI number of dead calves, VII Dead male calves VIII \% of dead male calves with respect to total number of dead calves; IX dead female calves; X \% of dead female calves with respect to total number of dead calves

Tab. 4. Age of sick calves originating from high production dairy tie-stall housing farm A

\begin{tabular}{lc}
\hline Month & Age of sick calves in days \\
\hline January & 81 \\
\hline February & 0 \\
\hline March & 80 \\
\hline April & 71 \\
\hline May & 62 \\
\hline June & 0 \\
\hline July & 0 \\
\hline August & 0 \\
\hline September & 71 \\
\hline October & 63 \\
\hline November & 64 \\
\hline December & 81 \\
\hline Average age & 71.62 \\
\hline
\end{tabular}

Tab. 5. Age of dead calves originating from high production dairy tie-stall housing farm A in days

\begin{tabular}{cc}
\hline Month & Age of dead calves in days \\
\hline January & 85 \\
\hline February & 0 \\
\hline March & 103 \\
\hline April & 79 \\
\hline May & 51 \\
\hline June & 0 \\
\hline July & 0 \\
\hline August & 0 \\
\hline September & 77 \\
\hline October & 58 \\
\hline November & 78 \\
\hline December & 87 \\
\hline Average age & 77.25 \\
\hline
\end{tabular}


calves, particularly in overcrowded facilities with poor microclimate conditions (low temperature and high humidity, high concentration of ammonia and draft) as well as in animals with impaired immunity. Infection of airways is a constant problem associated with seasonal flaring, particularly on the farms where zoohygienic measures are not properly performed. (Bugarski et al. 2005)

Wellbeing of calves related to housing conditions is most frequently compromised by inadequate ventilation, air flow and temperature as well as exposure to pathogenic microorganisms and parasites. In addition to information on housing conditions, in order to obtain full picture on wellbeing of the animals, feeding and certain management procedures must be also taken into account, such as method of watering or weaning of calves. Analysis of potential risks for wellbeing of farm animals points out to the possible cause of already present health-related and other problems in calves, as well as to the problems that may appear in the future (Relić and Bojkovski, 2010).

Viruses, bacteria and mycoplasmas (Mycoplasma bovis) are implied as the most common causes of diseases of the respiratory organs (Bugarski et al., 2005). Pathogenic effects of viruses and mycoplasmas favor subsequent pathogenic effects of the bacteria.

Bojkovski et al. (2011) reported that the most common isolates from the nasal swabs obtained from calves affected with respiratory infections were the following: Pasteurella multocida, Mannheimia haemolytica (Pasteurella haemolytica), Trueperella (Arcanobacterium) pyogenes, Haemophilus spp., as well as Klebsiella pneumoniae. Investigations presented in the paper confirmed earlier conclusion that Pasteurella multocida was the most predominant cause of respiratory diseases in calves originating from high production tie-stall housing dairy farms.

Namely, it has been known that calves are prone to cardiorespiratory and metabolic disorders that may be diagnosed as early as during the first several weeks of life. The reason for the above lies in incompletely formed organisms of the newborn calves, and accommodation to the extrauterine way of life must be rather fast in conditions of the contemporary beef cattle production (Bugarski et al., 2005, Radojičić et al.,2014).

Calf vitality may be influenced by mistakes made in management of pregnancy, particularly those related to feeding of cows during the last third of pregnancy (Radojičić et al., 2014).

\section{CONCLUSION}

Etiology of calve diseases in intensive breeding is most commonly multifactorial, with respiratory diseases being the most important health-related problems on our farms.

On a tie-stall housing farm the following bacteria were isolated in calves within a calendar year: Pasteurella multocida, Mannheimia haemolytica, Pasteurella spp, Histophilus somni, Haemophilus spp, Trueperella (Arcanobacterium) pyogenes, Escherichia coli, Klebsiella pneumoniae, nocardioform microorganisms, Pseudomonas aeruginosa, Salmonella Enteritidis, Salmonella Typhimurium. Intensive breeding of calves requires continuous monitoring of their health status and appropriate application of veterinary-prophylactic, hygienic-sanitary and zootechnical measures.

Acknowledgments This paper is supported by Ministry of Education, Science and Technological Development, Project TR 31071.

\section{REFERENCES}

1. Bojkovski J, Savić B, Pavlović I, Petrujkić Relić T, Rogožarski D (2011). The most common pathogenic causes of disease in dairy breed cattle and pigs in farm. Lucrări stiintifice medicină veterinară Timisoara, 19(1): 149-156.

2. Bojkovski J, Radojičić B, Petrujkić T,Borozan S (2008). A contribution to insight of the most important etiological factors with influence of farm animal health in Serbia. Proceedings of the International Symposium on new research in biotechnology, Bucharest, Romania, Biotehnology, seria F, Special volume: 101-114.

3. Bojkovski J, Radojičić B (2004). Najčešći poremećaji zdravlja teladi u ranom neonatalnom periodu i do četiri meseca starosti sa jedne farme visoko-mlečnih krava. Zbornik kratkih sadržaja 16. Savetovanje veterinara Srbije sa međunarodnim učešćem,: 50-51.

4. Broom DM (1991). Needs and welfare of housed calves. In: New Trends in veal calf production. Proceedings of the International Symposium on Veal Calf Production: 23-31.

5. Bugarski D, Lazic S, Petrović T, Milanov D, Bojkovski J, Vujanac I (2005). Infekcije disajnih puteva teladi. Veterinarski Žurnal Republike Srpske, vol. V, 3-4: 107-164.

6. Dobrić Đ, Dolores Z, Bojkovski J (1999). Baktreriološko ispitivanje klinički manifestne bronhopneumponije novorođene teladi. Zbornik kratkih sadržaja Prvog simpozijuma iz oblasti veterinarske nauke i prakse: 44 .

7. SRPS EN ISO 6579:2008 (2008). Mikrobiologija hrane i hrane za životinje - horizontalna metoda za otkrivanje Salmonella spp.. Institut za standardizaciju Srbije: 19-20. 
8. Radojičić B, Bojkovski J, Jonić B, Ćutuk R (2014). Bolesti preživara, Univerzitet u Beogradu, Fakultet Veterinarske medicine, osnovni udžbenik: 150-186

9. Relić R, Bojkovski J (2010).: Housing conditions in calves welfare risk assessment. Journal of Agricultural Sciences. 55 (3): 283 - 292.

10. Rogan D, Lazić S, Pavlović R, Šamanc H (2010). Imunoprofilaksa respiratornog sindroma goveda, Veterinarski glasnik 64(5-6): 393-408.
11. Šamanc H, Damnjanović Z, Marković S, Jonić B, Pilipović S (1990). Primena leka Excenal (Ceftiofur-Na) u lečenju teladi sa respiratornim sindomom, Veterinarski glasnik 7:501-620.

12. Quin PJ, Carter ME, Markey BK, Carter GR (1998). Section 2: Bacteriology, p. 43-213. In: Quin PJ, Carter ME, Markey BK, Carter GR (eds), , Mosby International, London, England. 